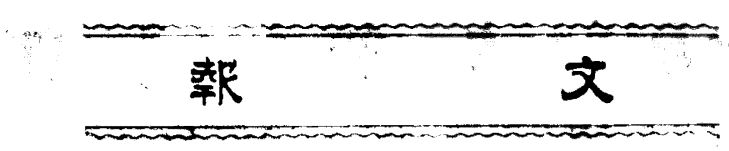

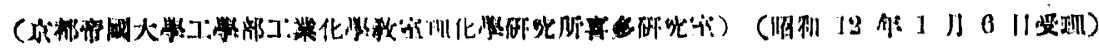

\title{
(70) 維素㛢導體の溶解機構に關する一考察
}

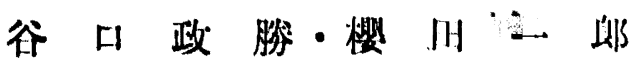

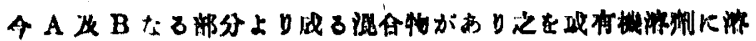

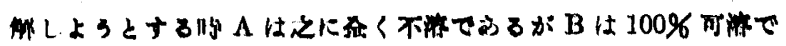

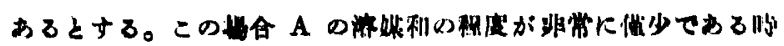

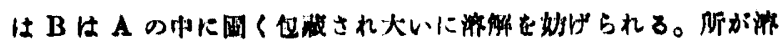

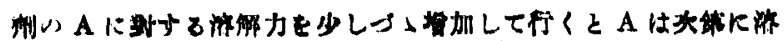

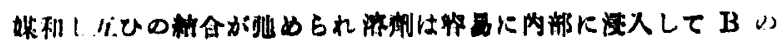

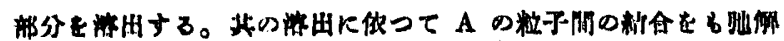

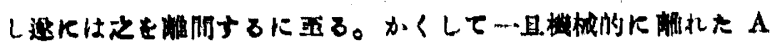

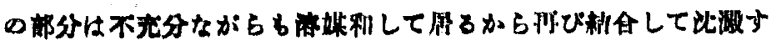

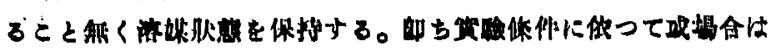

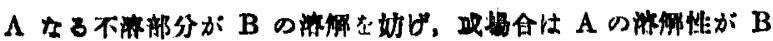

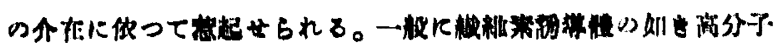

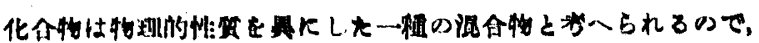

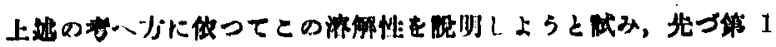

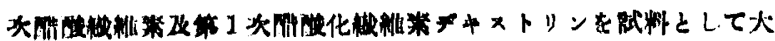

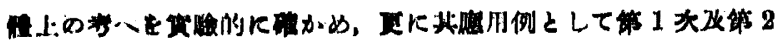

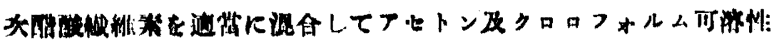

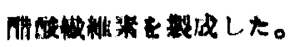

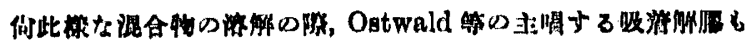

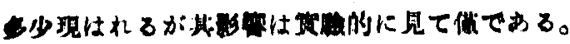

\section{精}

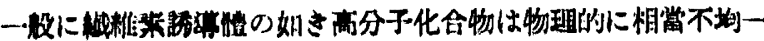

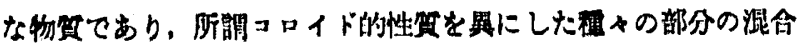

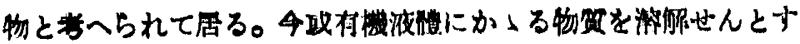

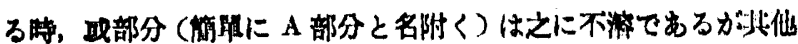

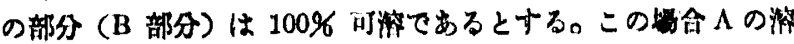

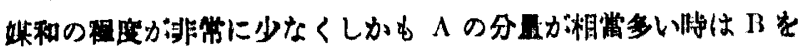

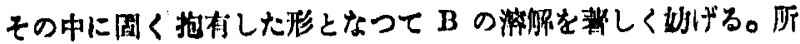

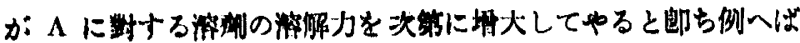

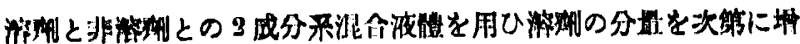

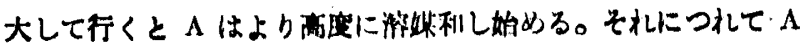

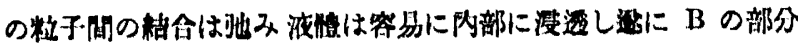

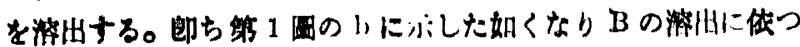

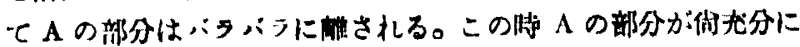

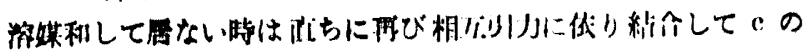

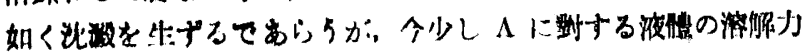

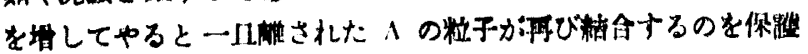

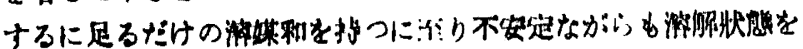

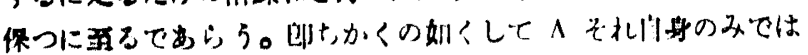

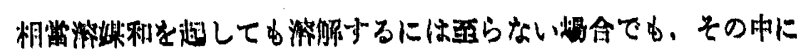

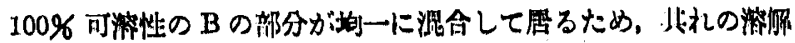

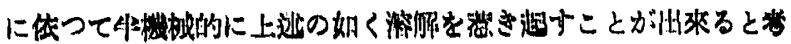

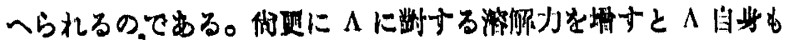

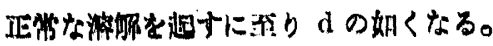

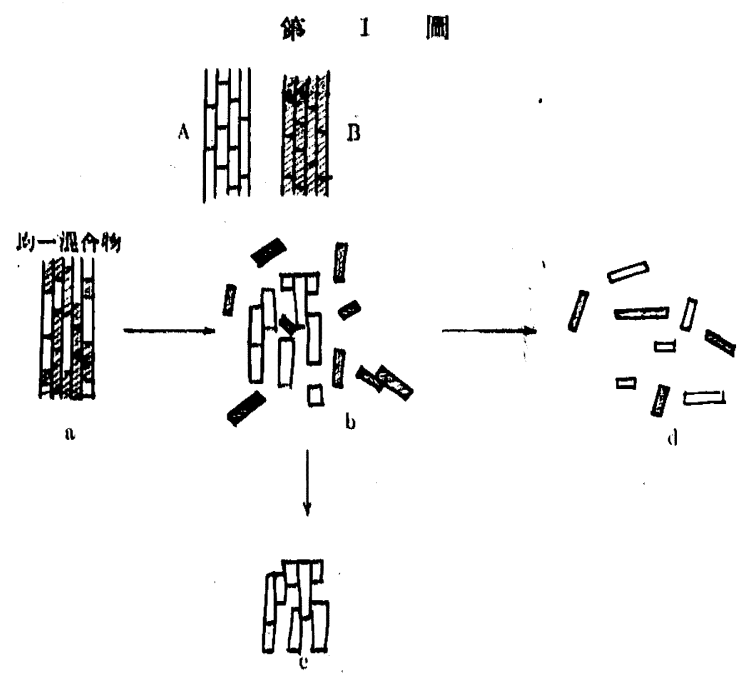

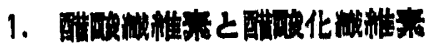
デキストリン泥合物の溶解

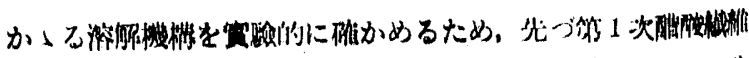

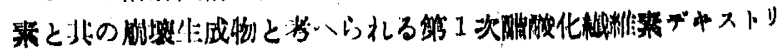

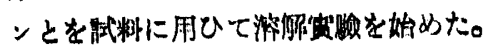

1）网斯料の演解度曲絈

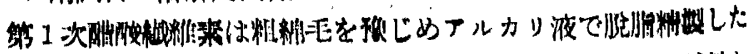

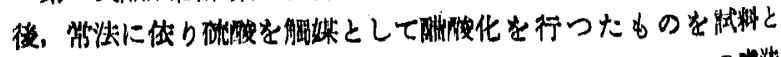

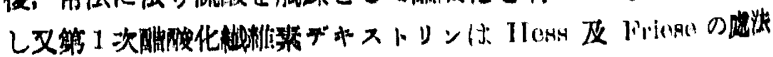
(Ann.,1926，450，40) に訨り赀つた。

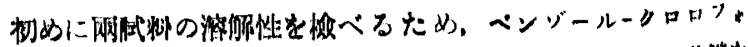

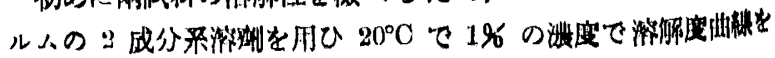

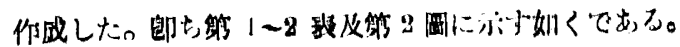

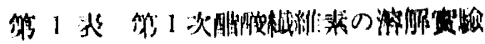

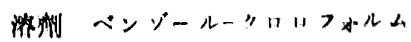

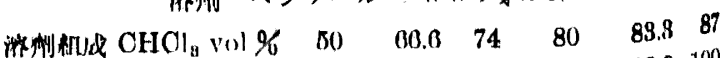
$\begin{array}{llrrrrrr}\text { 㳻湖度 } \% & 0 & 8.7 & 10.0 & 25.8 & 38.0 & 100\end{array}$ 
躬 3 数

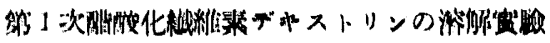

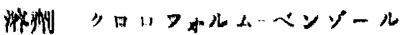

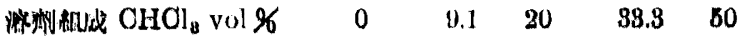
$\begin{array}{lllllll}\text { 僻庭 } \% & 11.7 & 14.7 & 24.2 & 40.6 & 100\end{array}$

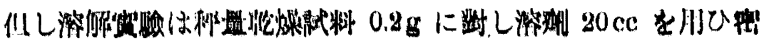

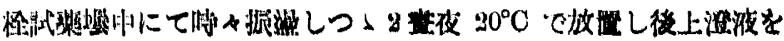

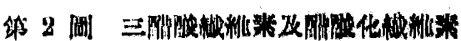

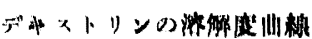

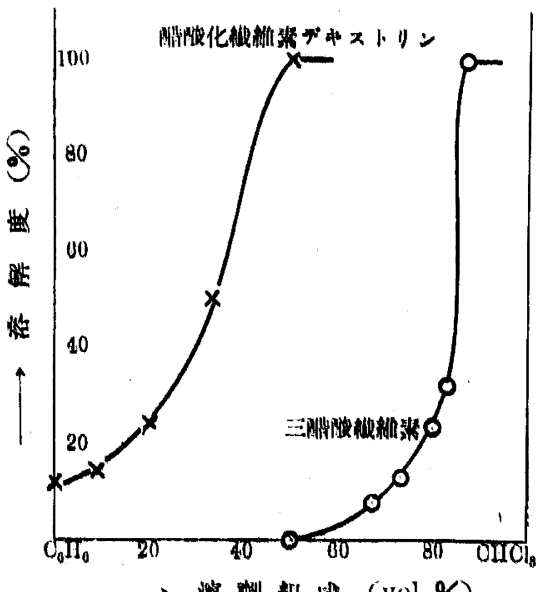

一一溂机战 (vol \%)
50・ビへっトで取

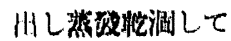
它国し，原弑料の

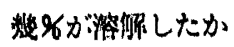
と云心㵋を海解度 \%として器はした ものである。

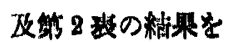
涌方したものであ

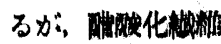
夷デヤストリンの 少はベンッ゙ールの みの内で毁に11\% 餘りすの湶解度を 䒹しクロロフ*ル ムが 50\% の所て

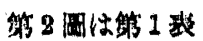

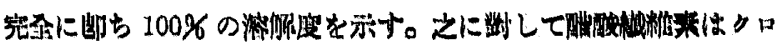

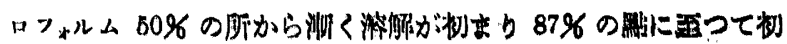

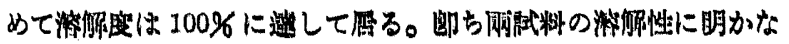
粗息が泌められる。

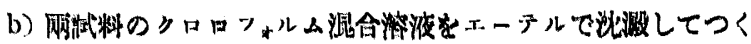
つた溜合物に就て

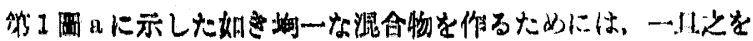

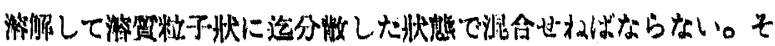

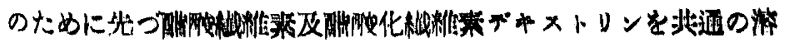

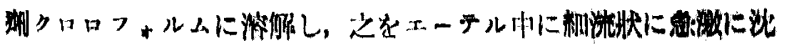

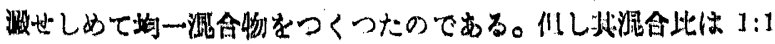

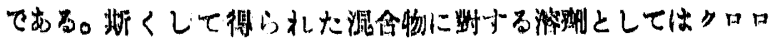

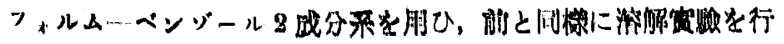

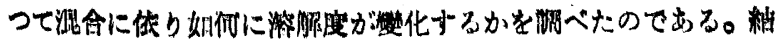

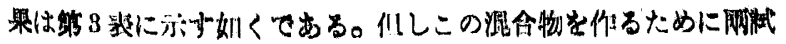

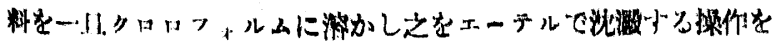

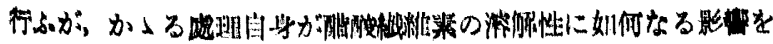

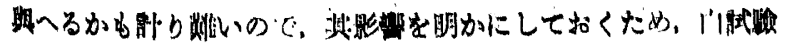

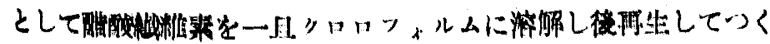

\section{的 3 羽}

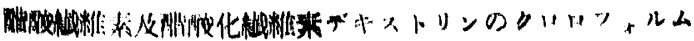

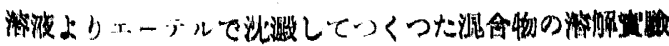

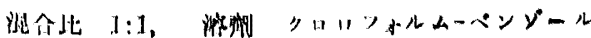

\begin{tabular}{|c|c|c|c|c|c|c|}
\hline 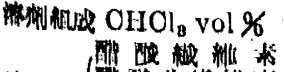 & $\begin{array}{r}50 \\
0\end{array}$ & $\begin{array}{r}60.6 \\
7.8\end{array}$ & 74 & $\begin{array}{l}80 \\
20.8\end{array}$ & $\begin{array}{l}88.3 \\
48.1\end{array}$ & $\begin{array}{r}87 \\
100\end{array}$ \\
\hline Wili & 100 & 100 & 100 & 100 & 100 & 100 \\
\hline 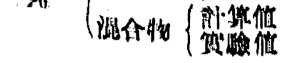 & $\begin{array}{l}50 . \\
17 .\end{array}$ & $\begin{array}{l}5.8 .9 \\
34.8\end{array}$ & 49.3 & 100 & $\begin{array}{l}74.1 \\
100\end{array}$ & $\begin{array}{l}100 \\
100\end{array}$ \\
\hline
\end{tabular}

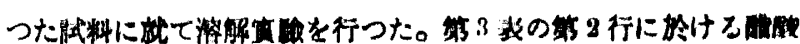

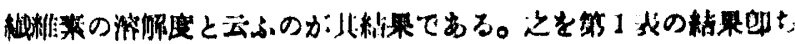

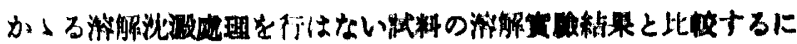

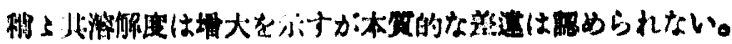

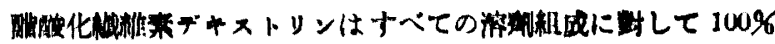

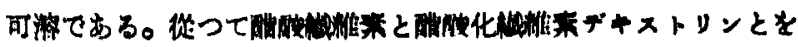

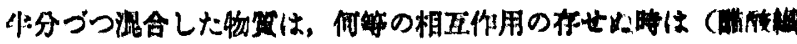

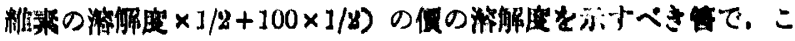

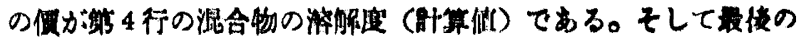

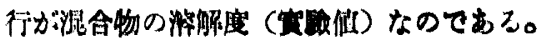

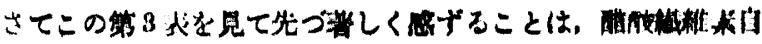

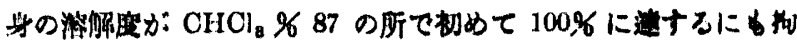
らナ゙，物一混合物に於ては CHCl。品か 80 の所て既に $100 \%$ の

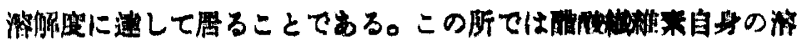

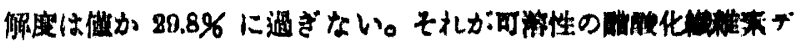

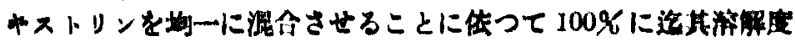
が墸加したのでむる。

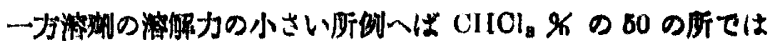

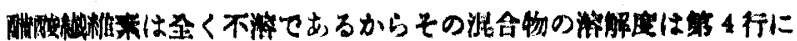

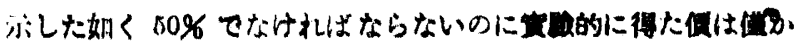

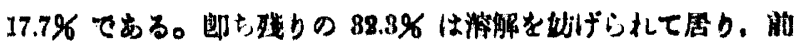

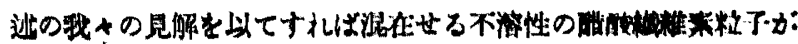

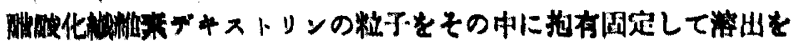

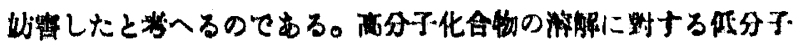

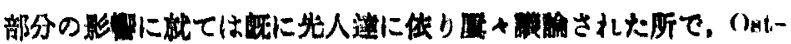

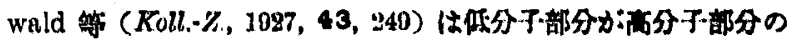

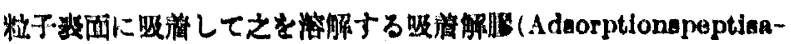

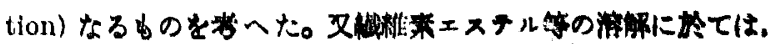

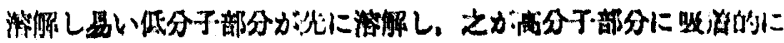

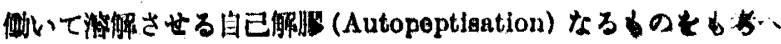

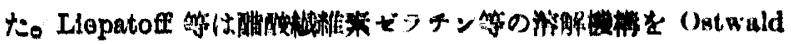

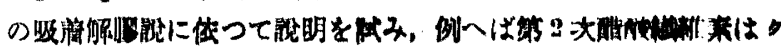

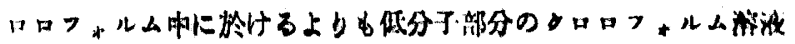

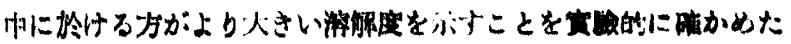
(Koll.-Z., 1834, 68, 65)。

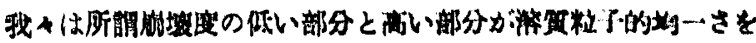

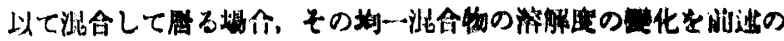

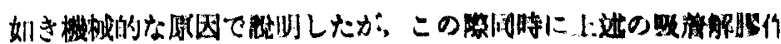

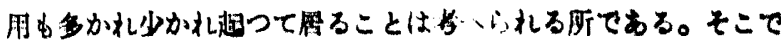

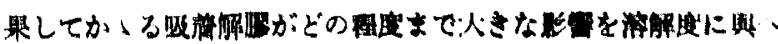

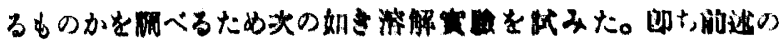

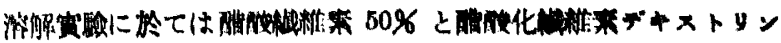

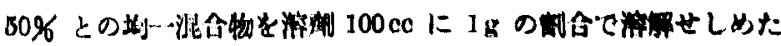

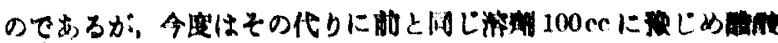

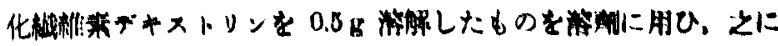

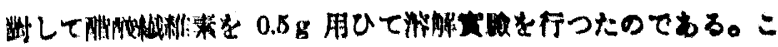

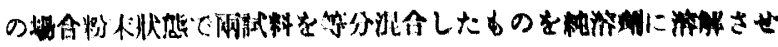

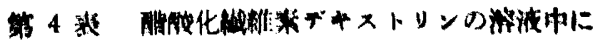

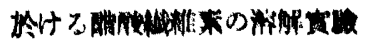

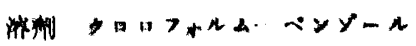

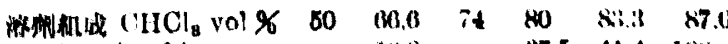

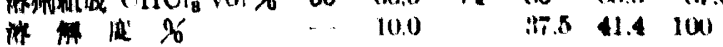




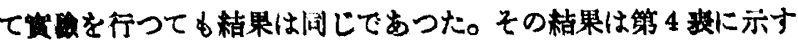
如くである。

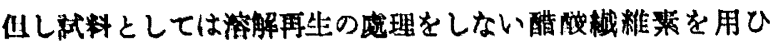
た。促つてこの結果を第 1 䘮の結果と比較するに，8.7\% に對し て 10.0\%，25.8\% に對して 37.5\%，38\% に對して 41.4\% と漸く

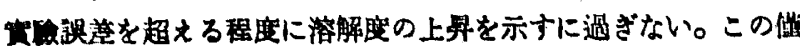

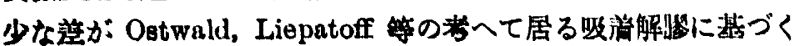

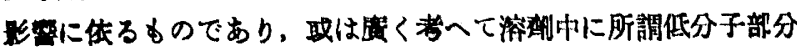
の在することに依り種なの原因で溶解度に及ぼす影整である。 所が之に對して均一混命物に於ては $\mathrm{CHCl}_{\mathrm{s}} 83.3 \%$ の所で或は 80\% の所で既に溶解度は $100 \%$ に達し段连ひに大きな溶解度の 增加が势められる。

印ち不均一混合物より成る高分子化合物の溶解度は，天然物に 胃ら机る如く低分子部分が溶筧粒子的な均一さで混在することに

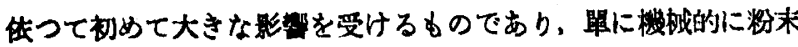

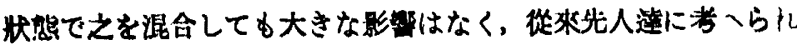

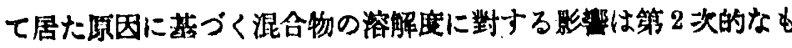

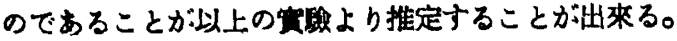

c) 雨料料のクロロフォムム混合溶液よりつくつたフイルムに就

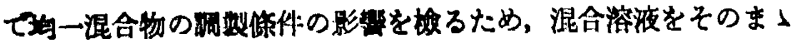

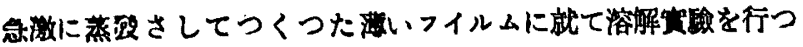
た。共結果は笰 5 俵に示す如くである。

\section{第 5 裴}

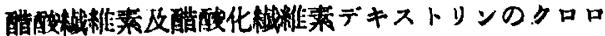

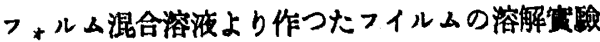

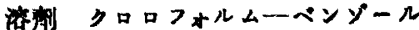

\begin{tabular}{|c|c|c|c|c|c|c|}
\hline 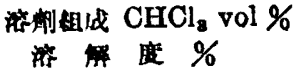 & 50 & 66.6 & 74 & 80 & 83.3 & 87 \\
\hline 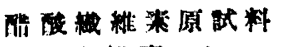 & 0 & 8.7 & 10.8 & 25.8 & 38.0 & 100 \\
\hline 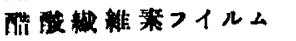 & - & - & 11.2 & 44.4 & 58.6 & 10 \\
\hline 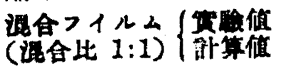 & $\begin{array}{l}27.0 \\
50\end{array}$ & $\begin{array}{l}44.1 \\
54.3\end{array}$ & $\overline{-}$ & $\begin{array}{l}73.5 \\
62.9\end{array}$ & $\begin{array}{l}100 \\
69.0\end{array}$ & \\
\hline 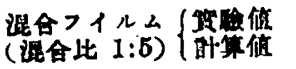 & $\begin{array}{l}56.0 \\
83.3\end{array}$ & $\begin{array}{l}84.0 \\
84.8\end{array}$ & $\begin{array}{l}86.7 \\
85.2\end{array}$ & $\begin{array}{c}100 \\
90.7\end{array}$ & $\begin{array}{l}100 \\
98.1\end{array}$ & \\
\hline
\end{tabular}

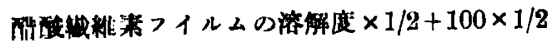

沘合比 1:5 の针算做

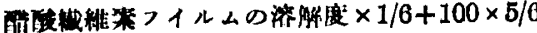

第 5 表に於て醋校粈維素フイルムの溶解度々は，混合フイルム をつくるのと同じ你件でクロロフォルム溶液よりつくつた醋酸掝

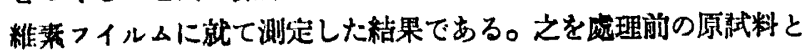
比校するに相當溶解度の虽は䏆して居る。次に醋酸做維素及醋酸 化械維素デキストリンの混合化を $1: 1$ 或は $1: 5$ としてつくつた混

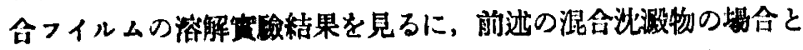
全く倾们の等しい䑩果を示して居り，郎ち溶都の溶解力の小さい 所に於ては湥解度は翼常に小さく溶期の溶解力が大きくなるにつ

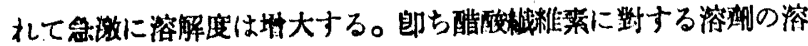

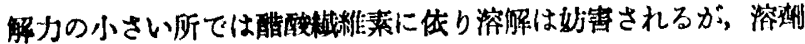

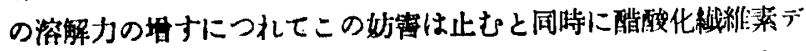
キストリンの介在に依る淙解の促淮が急激に迅るとの初めの我↔

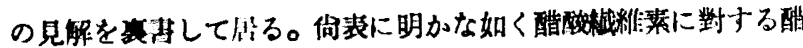

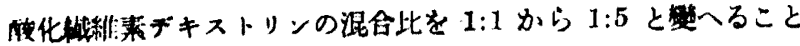
に传り，楁侔の妨害度は娍少し一方溶解の促進はより早く起る。
之は鳘洘へられる所である。

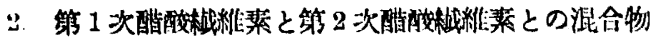

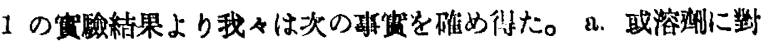
しAなる物筫は $30 \%$ 程度の溶解度を有し，B は $100 \%$ の溶份 度を有する時，A 及 B の均一混合物は $100 \%$ の溶解度を有し得 るっ但しこの坦合均一混合物とは兩者を共に共通の溶劑に一旦溶 解して溶资粒子状にまで分散した状態で混合した後再生した混合

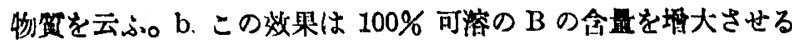
ことに依りより大きくすることが出來る。

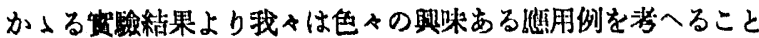

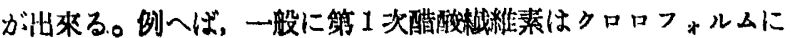
100\% 可溶であるがアセトンには餘り溶けない，所が第 2 次醋酸 粈䊒来はクロロフォルムには馀り溶けないがアセトンに $100 \%$ 可 溶である。然らば第 1 次醌酸㖪維菜に第 2 次醋酸粈維素を㚬一に 混合することに依り之をアセトン可溶性にすることは计來ないか

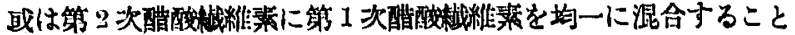
に传りクロロフォルム可溶性の混合物が涽來ないかと云ふことが 考へられる。

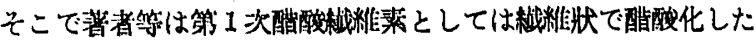
三醌酸ラミ一を用ひ，第 2 次醋酸粈維装としては市眅のものを用 ひ、兩試料を種↔の制合に䀧酸メチルに溶解し，之より混合フィ ルムをつくり種々の溶劑に對する之の溶解度を测定した。溶洲と

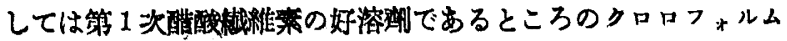

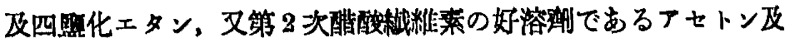

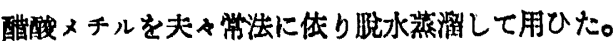

實驗の絬果は第 6 表に示す。

第 6 表 第 1 次酷酸粈維素之第 2 次醋酸㖪維素 との泥合フルイムの溶解度

\begin{tabular}{|c|c|c|c|c|c|}
\hline \multirow{2}{*}{\multicolumn{2}{|c|}{ 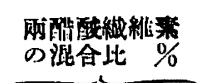 }} & \multicolumn{2}{|r|}{ 淮 } & \multicolumn{2}{|c|}{ 解 庭 \% } \\
\hline & & & 等 酸 & 万व & Rer \\
\hline 第 1 次 & 第2次 & テセトン & 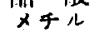 & フォルム & 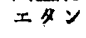 \\
\hline 0 & 100.0 & 100 & 100 & 29.1 & 12.1 \\
\hline 22.5 & 77.5 & 100 & 100 & 47.5 & 49.1 \\
\hline 54.8 & 45.2 & 100 & 100 & 91.5 & 87.0 \\
\hline 71.0 & 29.0 & 100 & 100 & 100 & 100 \\
\hline 86.0 & 14.0 & 87.0 & 92.1 & 100 & 100 \\
\hline 100.0 & 0 & 82.5 & 62.5 & 100 & 100 \\
\hline
\end{tabular}

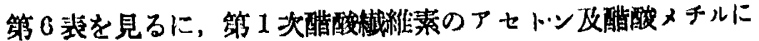

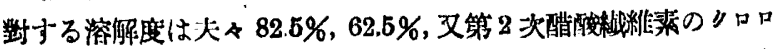
フォルム及四㮣化エタンに對する溶解度は夫ょ $29.1 \%$ 及 $12.1 \%$ に過ぎない。所が兩者を次第に混合させることに依り，郎ち第》

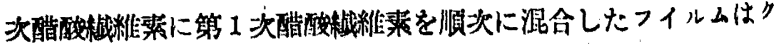

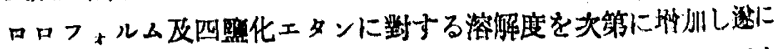
は 100\%可溶の點に造する。同時にアセトン及醌酸メチルに對与

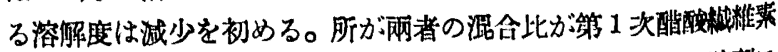

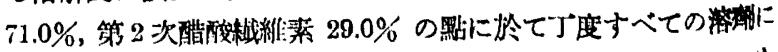
㷣して 100\%の溶解度を示す。郎ちこの混合比の混合フイルムを

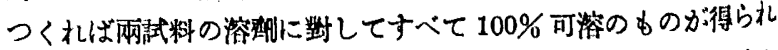
るのである。この他著者等は椣々の栦維素エステルの混合フイル

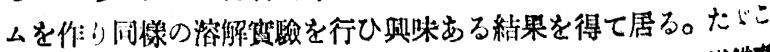

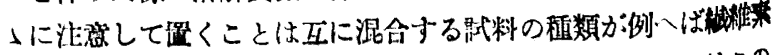

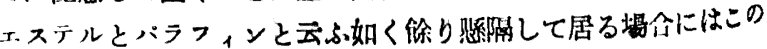




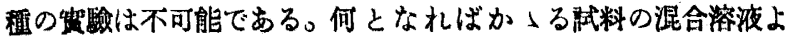

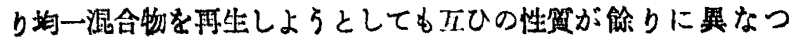

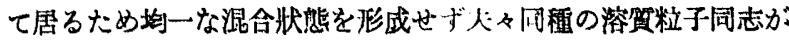

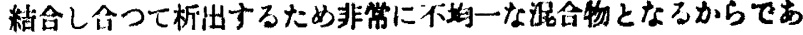
引。

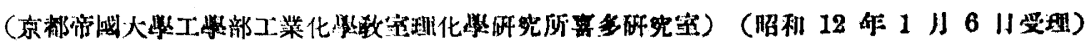

（71）3 層 法摭散党 驗

谷口政 勝・桜 田一郎

\section{要}

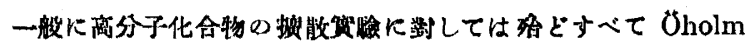

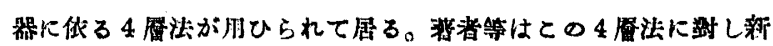

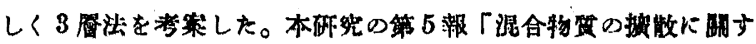

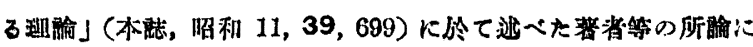

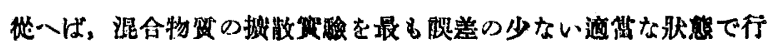

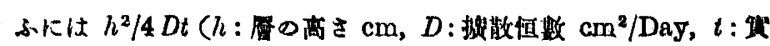

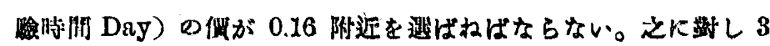

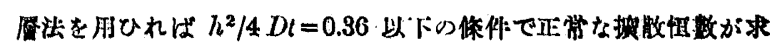
め得られる。促って 4 啳法の代りに 3 層法を用ひることに化り

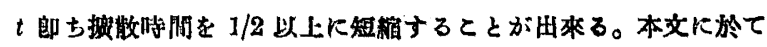

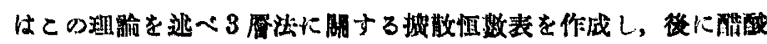

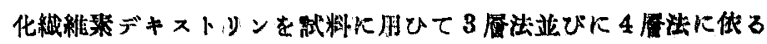

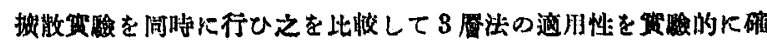

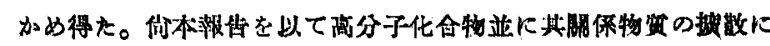

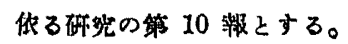

\section{粕霄並に理論の.部}

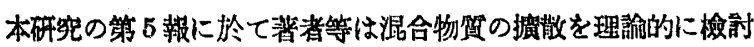
し，其撼散は單一物貿の挀散と近似的に同楾に取拨ひ得ることを 明かにした（谷口・贸田，本誌，昭和 $11 ， 39 ， 699$ )。郎ち混合物 筫各成分の症散恒数を $D_{1}, D_{2}, \cdots D_{n}$ とし之等と

$$
1 / \sqrt{D}=\frac{1}{n} \cdot \sum_{i=1}^{i \infty n} 1 / \sqrt{D i}
$$

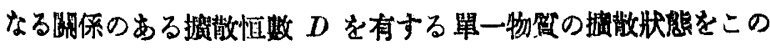

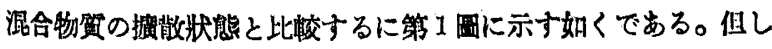

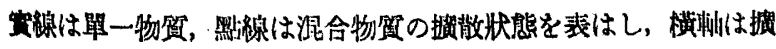

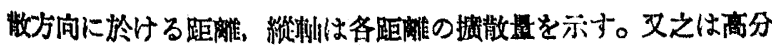

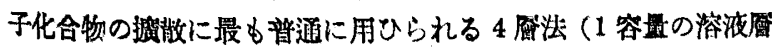

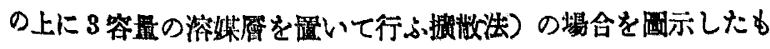

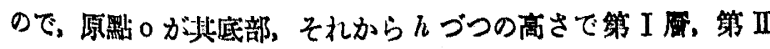

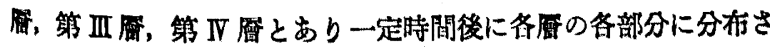
れた掘敞量を曲緗で示したすのである(第1國 a, b, c)。

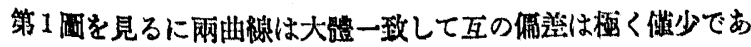
るが，懒敞量の少い最上詹の部分だけを考へると掘散量自身が微

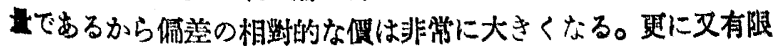

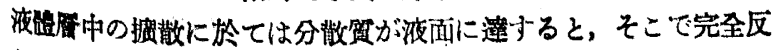

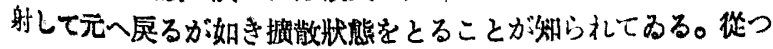

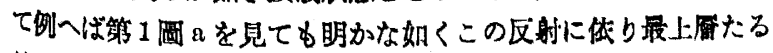

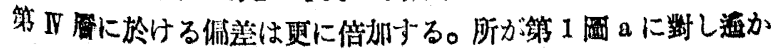

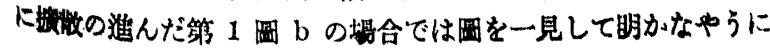
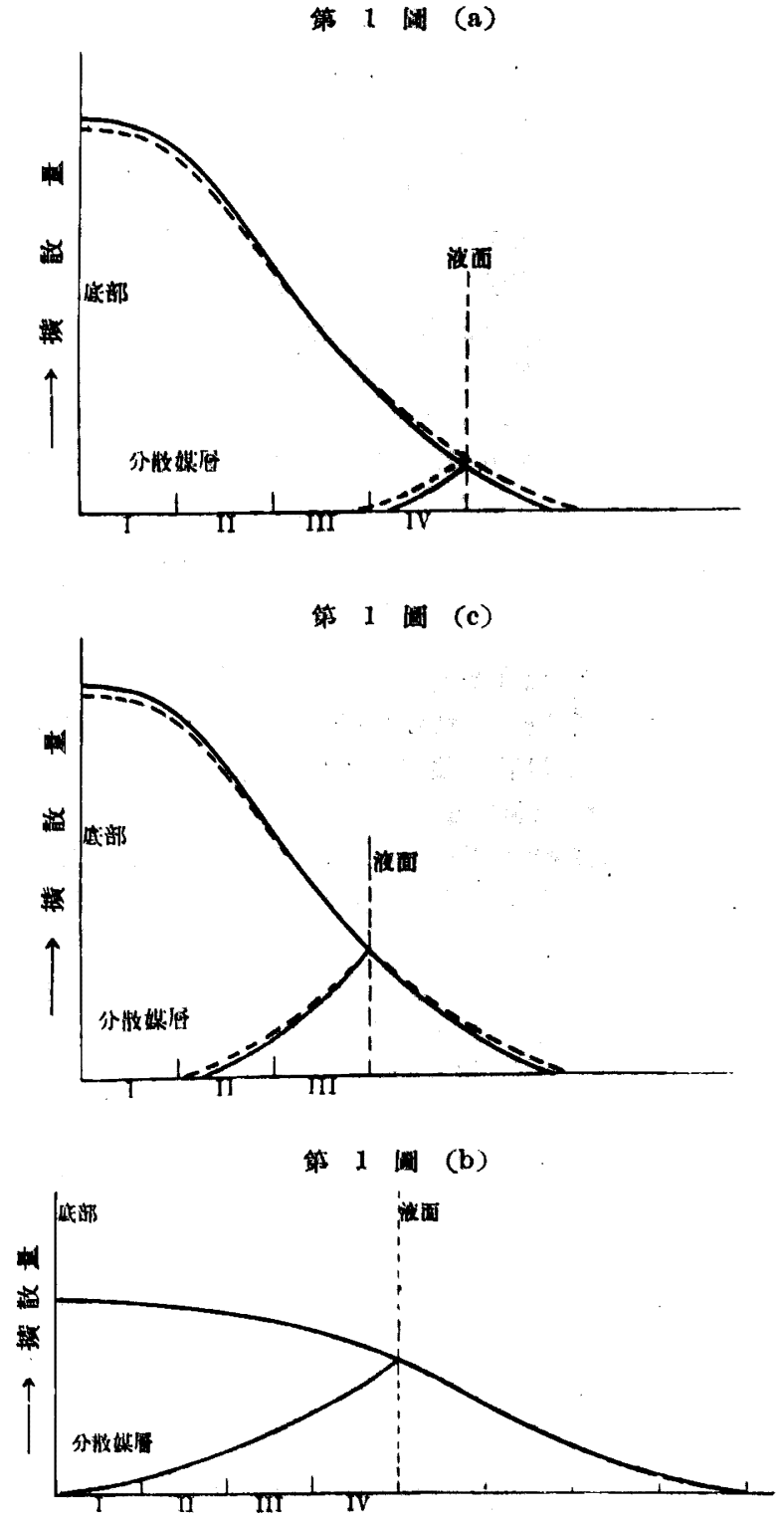

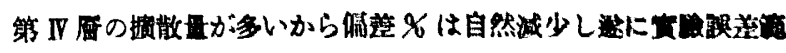

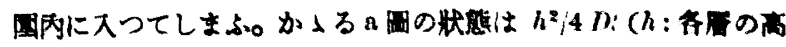

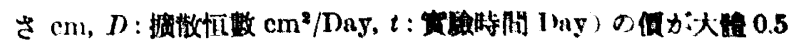

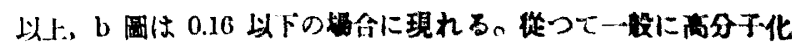

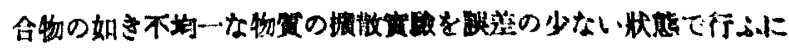

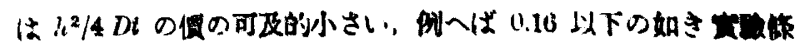

